\title{
IMPORTANCE OF ABSCISIC ACID (ABA) IN THE IN VITRO CONSERVATION OF CASSAVA (Manihot esculenta CRANTZ)
}

\author{
L. Pedro Barrueto Cid ${ }^{1 *}$, and Luiz L.C.B. Carvalho ${ }^{1}$
}

\begin{abstract}
A B S T R A C T
The conventional technology for in vitro plant conservation for cassava (Manihot esculenta Crantz) germplasm collections is laborious due to the need for several subculturing procedures per year. This practice implies high costs for medium preparation, tissue culture tubes, timeconsuming labor, risks of contamination, mislabeling of accession, and the need for large growth chambers. We have developed a new procedure using in vitro cultivated nodal axillary buds treated with different abscisic acid (ABA) concentrations to reduce the time for recycling transplants cultivated in a SP basic nutritive medium. Nodal explants were stored for three months with ABA. Plants were obtained after nodal axillary buds were placed in SP medium without ABA. Results indicated that 20 and $30 \mu \mathrm{M}$ ABA induced bud dormancy and delayed sprouting without affecting subsequent growth of plants after treatment.
\end{abstract}

Key words: tissue culture, dormancy, Manihot esculenta.

\section{INTRODUCTION}

In vitro conservation of cassava germplasm collections involves laborious work due to the high frequency of sub-culturing, which is carried out every 60 to $70 \mathrm{~d}$, depending on the access. Alternative procedures have been proposed based on manipulation of environmental factors, such as room temperature, medium composition and alterations in concentration focused on sucrose, mannitol (Roca, 1984) and silver nitrate (Mafla et $a l ., 2004)$. However, results have been variable and accession-dependent. New germplasm accession was recently introduced at the Genetic Resources and Biotechnology of Empresa Brasileira de Pesquisa
Agropecuária, Brasilia (EMBRAPA) for conservation that misses information of in vitro culture behavior and response. In vitro storage is very important because with this technique the troublesome process of maintenance and conservation of genetic resources under field condition can be eliminated. For in vitro conservation, the preservation protocols should reflect the objective of achieving a maximum survival rate, as well as genetic stability with minimum subculture frequency (Naidu and Sreenath, 1999).

Given the commercial interest in this genetic material, as well as its rare occurrence as a spontaneous mutant (Carvalho et al., 2000; 2004), there is a need to develop new in vitro conservation technology. An alternative approach could be to add hormones as growth retardant agents in SP medium, which is a modified Murashige and Skoog (1962) medium (MS medium) developed by Barrueto Cid (2005) based on the dilution of a macronutrient composition that allows overall nutrient balance, and was applied for cassava (Barrueto Cid et al., 2007), and several other species (Barrueto Cid and Durzan, 2003; Barrueto Cid et al., 2004). Abscisic acid (ABA) has been reported to show strong pleiotropic inhibitory effects on plant growth and seed embryo germination (Fong et al., 1983; Leung and Giraudat, 1998; Lemos, 2005).

Given the properties of ABA, it has been used in tissue culture for different purposes in Vitis vinifera L. (Perl et al., 1995), Poa pratensis L. (Ark et al., 1991), several forest trees (Gupta and Kreitinger, 1993), coffee (Naidu and Sreenath, 1999) and Medicago sativa L. ( Rudús et al., 2006). No attempt was found to explore the properties of ABA in tissue culture conservation of cassava germplasm (Unnikrishnan and Sheela, 2000; Fauguet, 2001; Alves, 2004).

\footnotetext{
${ }^{1}$ EMBRAPA, Recursos Genéticos e Biotecnologia, CENARGEN, Caixa Postal 02372, CEP 70770-900, Brasília DF, Brasil. E-mail: lpbcid@gmail.com *Corresponding author. Received: 21 June $2007 . \quad$ Accepted: 11 March 2008.
} 
The objective of this experiment was to test the possibility of using ABA at different concentration in SP medium to retard bud sprouting and in vitro plant growth, as well as to recover explants.

\section{MATERIALS AND METHODS}

The experiments were carried out at the tissue culture facilities of EMBRAPA Genetic Resources and Biotechnology, Brasilia, DF., Brazil, in 2007. In vitro plants of sugary cassava were used as donors of experimental nodal axillary buds. All experiments were carried out under standard in vitro plant culture conditions: $25 \pm 2{ }^{\circ} \mathrm{C}$ with $16: 8 \mathrm{~h}$ photoperiod at a photon flux density of $50 \mu \mathrm{m} \mathrm{m}^{-2} \mathrm{~s}^{-1}$ from a cool fluorescent tube. In vitro plants were standardized for size (50-70 $\mathrm{mm}$ long) and used to collect node axillary buds that were cultured in Petri dishes with SP medium supplemented with $0,5,10,20$, and $30 \mu \mathrm{M}$ of ABA. SP basal medium consisted of half-strength MS macrosalt, MS microsalt without IK (mg L-1): $\mathrm{MnSO}_{4} \cdot 4 \mathrm{H}_{2} \mathrm{O} 22.0$, $\mathrm{ZnSO}_{4} .7 \mathrm{H}_{2} \mathrm{O} 8.0, \mathrm{H}_{3} \mathrm{BO}_{3} 6.0, \mathrm{Na}_{2} \mathrm{MoO}_{4} .2 \mathrm{H}_{2} \mathrm{O}$ 0.25, $\mathrm{CuSO}_{4} .5 \mathrm{H}_{2} \mathrm{O} 0.25, \mathrm{CoCl} .6 \mathrm{H}_{2} \mathrm{O} 0.25$ and half-strength MS Fe-EDTA; $1 \mathrm{mg} \mathrm{L}^{-1}$ each of: calcium panthotenate, pyridoxine $\mathrm{HCl}$, thiamine $\mathrm{HCl}$ and nicotinic acid; inositol $50 \mathrm{mg} \mathrm{L}^{-1}$, sucrose $20 \mathrm{~g} \mathrm{~L}^{-1}$ and Phytagel $2.5 \mathrm{~g}$ $\mathrm{L}^{-1}$. The $\mathrm{pH}$ was adjusted to 5.8 before autoclaving at $121^{\circ} \mathrm{C}(0.2 \mathrm{MPa})$ for $20 \mathrm{~min}$.

Five explants from accession CAS36.18 and CAS36.3 were cultured for $90 \mathrm{~d}$ and replicated three times. After this period, the explants were allowed to germinate and grow in SP medium without ABA for a period of $45 \mathrm{~d}$. Bud sprouting, in vitro plant recover after bud dormancy period, and in vitro plant growth were recorded by photo documentation, counting germinated sprouted buds and aerial plant part lengths.
Several preliminary tests were performed before full application of a completely randomized experimental design that was performed once. Explants distribution in the growth chamber bench was randomized twice a week. Data analyses were performed by variance estimation (ANOVA) and the Tukey test for the mean values with significance probability of $\mathrm{P} \leq 0.05$. Values of sprouting percentage were transformed to arc sine before estimating the variance.

\section{RESULTS AND DISCUSSION}

ABA affects both bud sprout and shoots growth with the same pattern, depending on the concentration. Observations made at $90 \mathrm{~d}$ after treatment indicate full inhibition of bud sprouts and shoots growth for ABA concentration greater than $10 \mu \mathrm{M}$ (Table 1). ABA concentration of 0 and $5 \mu \mathrm{M}$ ABA showed no significant inhibitory effect on either parameter, but concentrations of $10 \mu \mathrm{M}$ inhibited bud sprouting and shoot lengths by approximately 4 -fold. With $10 \mu \mathrm{M}$ of ABA, roots were only partially affected (Figure 1B) while shoots showed a 4-fold inhibition (Table 1). However, ABA showed differential effects on shoot sprouts and roots at higher concentrations. While both roots and shoots showed full development in the control (without ABA), the same was not observed at $20 \mu \mathrm{M}$ of ABA (Figure 1C) and $30 \mu \mathrm{M}$ (picture not shown). Cumulatively, these results confirmed our initial hypothesis that ABA represses cassava axillary bud sprouting and shoot growth. In addition, it is possible that the response to $\mathrm{ABA}$ is not dependent on the cassava genotype.

After $45 \mathrm{~d}$ in SP medium without ABA, all explants showed growth and development. Fig. 1D shows plant aspect especially at level of $20 \mu \mathrm{M}$, at $30 \mu \mathrm{M}$ was seen

Table 1. Percentage of axillary bud sprouting and shoot lengths at 90 days of treatment with different ABA concentrations in SP medium on cassava genotypes Cas36.18 and Cas36.3.

\begin{tabular}{rrrrrr}
\hline ABA & \multicolumn{2}{c}{ Cas36.18 } & & \multicolumn{2}{c}{ Cas36.3 } \\
\cline { 2 - 3 } \cline { 5 - 6 }$(\boldsymbol{\mu} \mathbf{M})$ & Bud sprouting & Shoot length & & Bud sprouting & Shoot length \\
\hline & $(\%)$ & $(\mathrm{mm})$ & & $(\%)$ & $(\mathrm{m})$ \\
5 & $100.0 \mathrm{a}$ & $31.0 \mathrm{a}$ & & $100.0 \mathrm{a}$ & $28.0 \mathrm{a}$ \\
10 & $80.0 \mathrm{a}$ & $29.0 \mathrm{a}$ & & $83.3 \mathrm{a}$ & $27.3 \mathrm{a}$ \\
20 & $26.7 \mathrm{~b}$ & $8.7 \mathrm{~b}$ & & $33.3 \mathrm{~b}$ & $9.0 \mathrm{~b}$ \\
30 & $0.0 \mathrm{c}$ & $0.0 \mathrm{c}$ & & $0.0 \mathrm{c}$ & $0.0 \mathrm{c}$ \\
\hline
\end{tabular}

Same letter in a column indicates no significant difference according to the Tukey test $(\mathrm{P} \leq 0.05)$. 

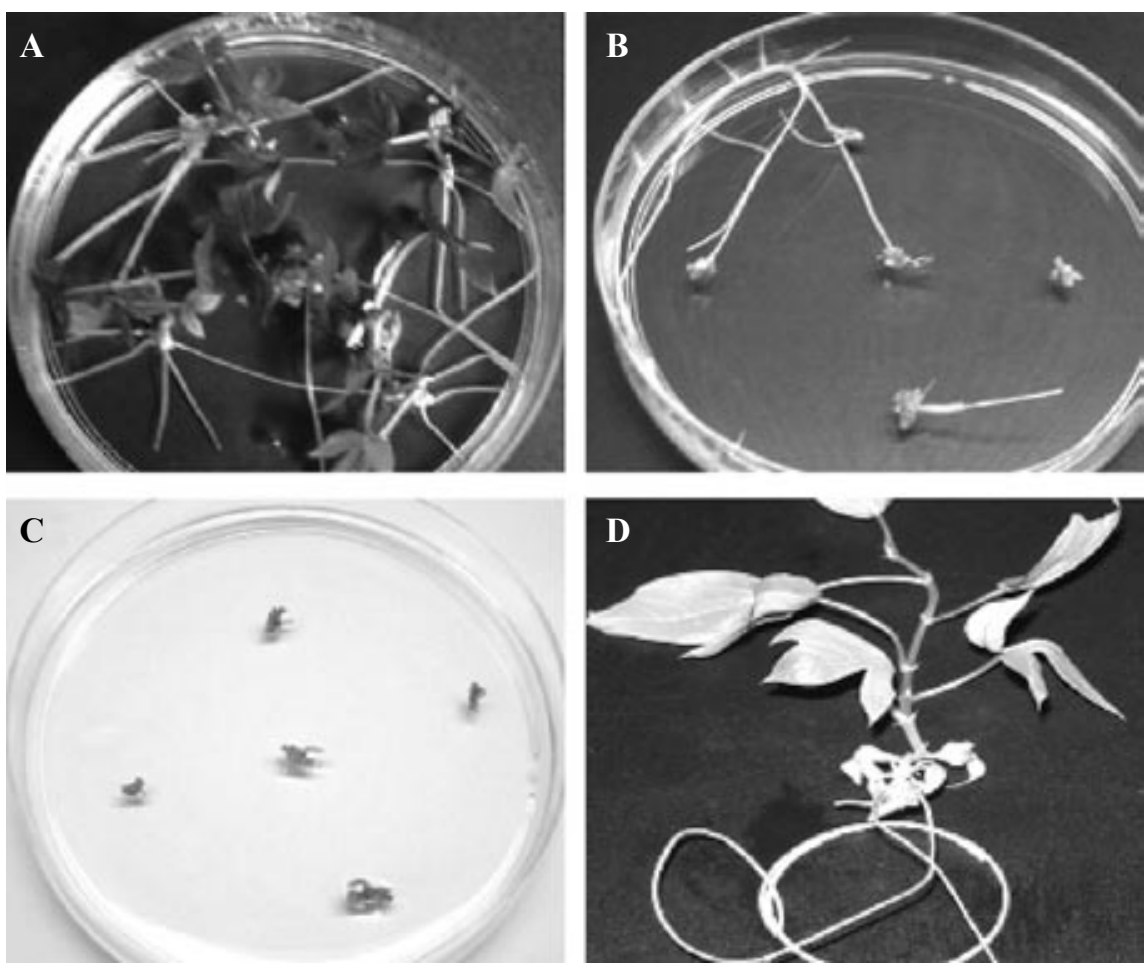

Figure 1. Effect of different abscisic acid (ABA) concentrations on nodes derived from in vitro plants and recover of landrace CAS36.18. A) Control (no ABA) bud sprouting; B) $10 \mu \mathrm{M}$ ABA effect on nodal explants for $90 \mathrm{~d}$; C) $20 \mu \mathrm{M}$ ABA effect on nodal explants during $90 \mathrm{~d}$; D) Regenerated in vitro plant after treatment of node with $20 \mu \mathrm{M} \mathrm{ABA}$ and growth on basic SP medium for $45 \mathrm{~d}$.

similar result (picture not shown). On the other hand, Figure 2 illustrates the vigorous stem length of both accessions in all ABA concentrations. The plantlet sizes reached, in terms of tissue culture, is very adequate and denotes favorable in vitro conditions and shows as well that 20 and $30 \mu \mathrm{M} \mathrm{ABA}$ did not affect subsequent plant growth. In addition, from in field conditions it is possible to assume that such results do not exclude the possibility of ABA having a protective role during the dry season, when cassava axillary buds remain in dormancy. However, during the raining season, when there are not stressful conditions, axillary bud can reassume sprouting and growth, and consequently $\mathrm{ABA}$ catabolism may be stimulated.

With the in vitro technique, ABA seems to be incorporated into axillary buds in the prior period. This could have resulted in decreased ABA levels due to its catabolism and in the absence of abiotic stress under the new in vitro conditions. More research is needed to understand ABA catabolism, i.e., degradation and conjugation process, in cassava and in other plants. More information is also needed for signaling pathways, gene expression, messenger RNA, enzymes, binding sites and regulatory mechanisms (Milborrow, 2001; Hirayama and Shinozaki, 2007; Ren et al., 2007).

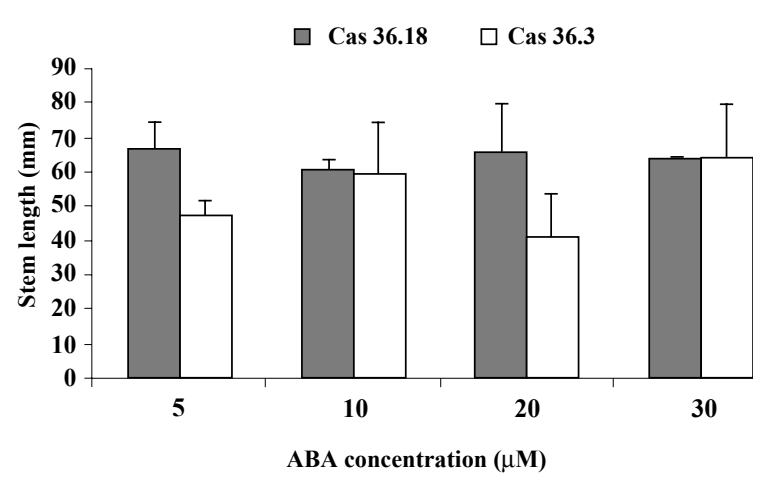

Figure 2. Plant growth after abscisic acid (ABA) treatment of buds of two genotypes and regrowth in basic SP medium for $45 \mathrm{~d}$. 
This is the first report of the effect of ABA on in vitro plant bud sprouting and growth retardation with cassava. Results demonstrated that ABA treatment of in vitro plant buds at the appropriate concentration can be used to improve in vitro germplasm collection management, allowing for storing buds for longer periods than in vitro plants. This could reduce the transplanting cycle of accessions in our large germplasm collection. The use of other ABA concentrations with other plant species, such as potato (Solanum tuberosum L.), garlic (Allium sativum L.), and onion (Allium cepa $\mathrm{L}$.) could replace the use of toxic maleic hydrazide.

\section{CONCLUSIONS}

The present work confirmed the inhibitory effect of ABA on cassava axillary bud sprouting and on in vitro plant growth. ABA added to a nutritive medium, strongly inhibited bud sprouting at 20 and $30 \mu \mathrm{M}$ for 90 days without affecting subsequent recovery of plants in a basic medium without ABA. ABA could now be used in SP medium for in vitro cassava culture and to improve management of large germplasm collections by reducing labor requirements.

\section{R E S U M E N}

Importancia del ácido abscísico (ABA) en la conservación in vitro de la yuca (Manihot esculenta Crantz). L. Pedro Barrueto Cid ${ }^{1 *}$, y Luiz L.C.B. Carvalho' $^{1}$. La tecnología usual para conservación in vitro de colecciones de germoplasma de yuca (Manihot esculenta Crantz) es corrientemente laboriosa y emplea varias transferencias por año. Este procedimiento envuelve altos costos en preparación de medios, consumo de tiempo, riesgos de manipulación y necesidad de mucho espacio para la mantención de colecciones en cámaras de cultivos. Se desarrolló un nuevo procedimiento usando yemas axilares nodales cultivadas in vitro con diferentes concentraciones de ácido abscísico (ABA), con el objetivo de reducir los ciclos de transferencia de los cultivos mantenidos en un medio nutritivo básico tal como el SP. Los segmentos nodales fueron almacenados por tres meses en presencia de ABA. Las plantas fueron obtenidas después que los segmentos nodales fueron transferidos al medio SP sin ABA. Los resultados indican que 20 y $30 \mu \mathrm{M}$ de $\mathrm{ABA}$ indujeron una completa dormancia de yemas, sin afectar el desarrollo posterior de las yemas nodales y su consecuente conversión en planta.

Palabras clave: cultivo de tejidos, dormancia, Manihot esculenta.

\section{ACKNOWLEDGEMENTS}

The authors wish to express their special thanks for the financial support from the Programa Nacional de Pesquisa em Biotecnologia - CENARGEN (Project N ${ }^{\circ}$ 060302058); IAEA (Contract $\mathrm{N}^{\circ}$ 3188.) and also to our colleague Luiz Augusto Copati Souza, agronomist/M.Sc., for his important support in statistical support.

\section{LITERATURE CITED}

Alves, A. 2004. Sixth International Scientific Meeting of the Cassava Biotechnology Network (CBN). 8-14 March. CIAT, Cali, Colombia. Available at http:// www.ciat.cgiar.org/biotechnology/cbn/ (Accessed April 2008).

Ark, HF van, M.A.C.M Zaal, J. Creemers-Molenaar, and P. van der Valk. 1991. Improvement of the tissue culture response of seed-derived callus cultures of $\mathrm{Poa}$ pratensis L.: effect of gelling agent and abscisic acid. Plant Cell Tiss. Org. Cult. 27:275-280.

Barrueto Cid, L.P. 2005. El cultivo de tejidos. p. 31-53. In H. Prieto, M. Jordan, L.P. Barrueto, M.C.R. Cordeiro, y D.J. Durzan (eds.) Biotecnología vegetal. Instituto de Investigaciones Agropecuarias, Centro Regional de Investigación La Platina, Santiago, Chile.
Barrueto Cid, L.P., L.J.C.B. Carvalho, R.E.P. da Silva, e L. Soriano. 2007. Protocolo de micropropagação e conservação de 23 germoplasmas de mandioca (Manihot esculenta Crantz). Boletim de Pesquisa e Desenvolvimento $\mathrm{N}^{\circ}$ 187. 12 p. EMBRAPA, Recursos Genéticos e Biotecnologia, Brasília, D.F., Brasil. Available at http://www.cenargen.embrapa.br/publica/ trabalhos/bp187.pdf (Accessed April 2008).

Barrueto Cid, L.P., A.R.R. Cruz, and L.H.R. Castro. 2004. Somatic embryogenesis from the coffee cultivars: 'Rubi', Catuaí Vermelho 81', and 'IAPAR 59'. HortScience 39:130-131. 
Barrueto Cid, L.P., e D.J. Durzan. 2003. Efeito da cefotaxima na germinação, crescimento e brotação de gemas axilares, sob condições in vitro. Boletim de Pesquisa e Desenvolvimento $\mathrm{N}^{\circ} 44.14$ p. EMBRAPA, Recursos Genéticos e Biotecnologia, Brasília, D.F., Brasil. Available at http://www.cenargen.embrapa.br/publica/ trabalhos/bp049.pdf (Accessed April 2008).

Carvalho, L.J.C.B., G.B. Cabral, e L. Campos. 2000. Raiz de reserva de mandioca: Um sistema biológico de múltiplas utilidades. Série Documentos No 44.16 p. EMBRAPA, Recursos Genéticos e Biotecnologia, Brasília, D.F., Brasil.

Carvalho, L. J.C.B., C.R.B. Souza, J.M.C. Cascardo, C. Bloch Jr., and L. Campos. 2004. Identification and characterization of a novel cassava (Manihot esculenta Crantz) clone with high free sugar content and novel starch. Plant Mol. Biol. 56:634-659.

Fauguet, C. 2001. Fifth International Scientific Meeting of the Cassava Biotechnology Network. November 4-9, 2001. St. Louis, Missouri, USA. Available at http://www.danforthcenter.org/iltab/cassavanet/cbnv/ (Accessed April 2008).

Fong, F., J.D. Smith, and D.E. Koehler. 1983. Early events in maize seed development: i-methyl-3-phenyl-5-(3[trifluoromethyl]phenyl)-4-(1H)-pyridinone induction of vivipary. Plant Physiol. 73:899-901.

Gupta, P.K., and M. Kreitinger. 1993. Synthetic seeds in forest trees. p. 108-119. In M.R. Ahuja (ed.) Micropropagation of woody plants. Kluwer Academic Publishers, Dordrecht, The Netherlands.

Hirayama, T., and K. Shinozaki. 2007. Perception and transduction of abscisic acid signals: keys to the function of the versatile plant hormone ABA. Trends Plant Sci. 12:343-351.

Lemos, E.E.P. 2005. Ácido abscísico em plantas superiores: síntese e propriedades fisiológicas. p. 167-188. In Barrueto Cid, LP. (ed.) Hormônios vegetais em plantas superiores. EMBRAPA, Recursos Genéticos e Biotecnologia, Brasília D.F., Brasil.

Leung, J., and J. Giraudat. 1998. Abscisic acid signal transduction. Annu. Rev. Plant Physiol. Plant Mol. Biol. 49:199-222.
Mafla, G., J.C. Roa, C.H. Ocampo, G. Gallego, G. Jaramillo, and D.G. Debouck. 2004. Efficiency of silver nitrate for slow-growth conservation of cassava (Manihot esculenta Crantz). Determination of viability and genetic stability. In Alves, A. 2004. Sixth International Scientific Meeting of the Cassava Biotechnology Network (CBN). 8-14 March. CIAT, Cali, Colombia. Available at http://www.ciat.cgiar. org/biotechnology/cbn/sixth_international_meeting/ posters.htm (Accessed April 2008).

Milborrow, B.V. 2001. The pathway of biosynthesis of abscisic acid in vascular plants: a review of the present state of knowledge of ABA biosynthesis. J. Exp. Bot.52:1145-1164.

Murashige, T., and F. Skoog. 1962. A revised medium for rapid growth and bioassays with tobacco tissue cultures. Physiol. Plant. 15:473-497.

Naidu, M.M and H.L. Sreenath. 1999. In vitro culture of coffee zygotic embryos for germplasm preservation. Plant Cell Tissue and Organ Culture 55:227-230.

Perl, A., S. Shoshana, N. Sahar, and D. Holland. 1995. Establishment of long-term embryogenic cultures of seedless Vitis vinifera cultivars - a synergistic effect of auxins and the role of abscisic acid. Plant Sci. 104:193-200.

Ren, H., Z. Gao, L. Chen, K. Wei, J. Liu, Y. Fan, W.J. Davies, W. Jia, and J. Zhang. 2007. Dynamic analysis of ABA accumulation in relation to the rate of ABA catabolism in maize tissues under water deficit. J. Exp. Bot. 58:211-219.

Roca, W.M. 1984. Cassava. p. 269-301. In W.R. Sharp, D.A. Evans, P.V. Ammirato, Y. Yamada (eds.) Handbook of plant cell culture. MacMillan Publishing, New York, USA.

Rudús, I., E. Kepczynska, and J. Kepcznski. 2006. Comparative efficacy of abscisic and methyl jasmonato for indirect somatic embryogenesis in Medicago sativa L. Plant Growth Regulation 48:1-11.

Unnikrishan, M., and M.N. Sheela, 2000. Studies on media, explants and incubation conditions for in vitro conservation of cassava germoplasm. p. 425-430. In Carvalho, L.J.C.B., A.M. Tho, and A.D. Vilarinhos (eds). Proceedings IV International Scientific Meeting Cassava Biotechnology Network. EMBRAPA-CENARGEN, Brasilia, D.F. Brasil. 03-07 November 1998. 